\title{
DDX52 Gene
}

National Cancer Institute

\section{Source}

National Cancer Institute. DDX52 Gene. NCI Thesaurus. Code C106433.

This gene plays a role in both RNA binding and ATP hydrolysis. 